\section{3. 電荷分布および極性}

最後にベンジル基の電荷分布および双極子能率につい ての計算値を掲げると
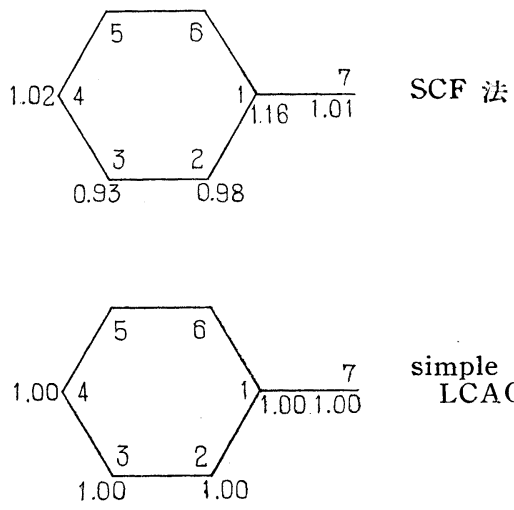

simple

LCA.O 法

第 4 図 ベンジル基の電荷分布

および $\mu($ ベンジル基 $)=0.27 \times 10^{-19} \mathrm{e} . \mathrm{s} . \mathrm{u}$.となる。

結

語

ベンジル基の電子状態に関する LCAO SCF の取扱 いに関し，われわれは7電子系の代りに6電子系を用い て計算を行い，最後に若干の補正を施した上ラジカルに 利用したのであるが，乙の方法はある程成まで有効であ ると思われる。ただし，この結果を簡単な LCAO 法の 絓果と比較すると，電子間斥力がかなりに影響している ため，仙者は必ずしも一致していないが，イオン化電压 等については垁験值とかなりよい一致を見た。

終りに種々御指導を賜わった当教室の志田正二教授, 九里善一郎氏，樋口治郎氏，小垍宏氏扣よびベンジル 基のメチル唀導体に関するデータを示されたLossing 博士に厚く謝意を表する。

（東京工業大学有機化学教室，東京都目黒区）（昭和 30 年 11 月 22 日受理）

\title{
有機イオウ化合物に関する研究（第 $\mathbf{2}$ 報)*
} 酸ヒドラジドの含イオウ誘導体について： チオホルミルベンズヒドラジドのニ，三の反応 加 藤 博**・佐 藤 菊 正**.大田 正 樹

著者の一人大田はさきに酸ヒドラジドにジチオギ酸力 リウムを作用させて得られるチオホルミル化合物を濃 硫酸で閉環すると，1,3,4-チオジアゾール誘導体の得ら れることを報告した1)。とのような含イオウ複素環化 合物の 合成に関連して，その原料となる酸ヒドラジド のイオウを含む誘導体，たとえばチオホルミル化合物 (RCONHNHCHS)，あるいはアシルジチオカルバジン 酸 (RCONHNHCSSH) の誘導体の性質を調べる必要 から，第 1 報ではフェニルヒドラジンのチオホルミル誘 導体のアシル化に対する挙動について報告したが，今回 はチオホルミルベンズヒドラジドについて二, 三の反応 を試みた結果について報告する。

チオホルミルベンズヒドラジドには I， II の互要黑性

* 前報 (第 1 報) T. Sato, M. Ohta, Bull. Chem. Soc. Japan 27, 624 (1954).

** 横浜国立大学化学工業科.

1）大田, 萩原, 水島, 苩学雑誌 73, 701 (1953).
体の存在が考えられるが，炭酸水䒺ナトリウム水に可溶 な点から見て主としてチオール型の II として存在するも のと思われる。そのナトリウム塩（II）にヨウ化エチル を作用させると $\mathrm{N}$-ベンゾィルーN'-エチルメルカプトメ チレンヒドラシン (N) を生じ，乙れにアニリンを常温 で作用させると $\mathrm{N}$-ベンゾィル- $\mathrm{N}^{\prime}$-アニリノメチレンヒ ドラシシ（V) を生じる。Vはチオホルミルベンズヒド ラジドに室温でアニリンを作用させても得られる。 モノクロル酶酸ナトリウムを縮合させると，カルボキシ メチルメルカプト化合物（VI）は得られないで, VIの加 水分解で生じたと考光られる $\mathrm{N}$-ベンゾイル-N'-ホルミ ルヒドラジン（VII）を生じる。クロルアセトフニ ンを作用させるとフェナシルメルカプト化合物（价）が 単離できる。

チオホルミルベンズヒドラジド（I， I ）はチオホル ミルフェニルヒドラジンと同様に種々のアジ誘導体を 


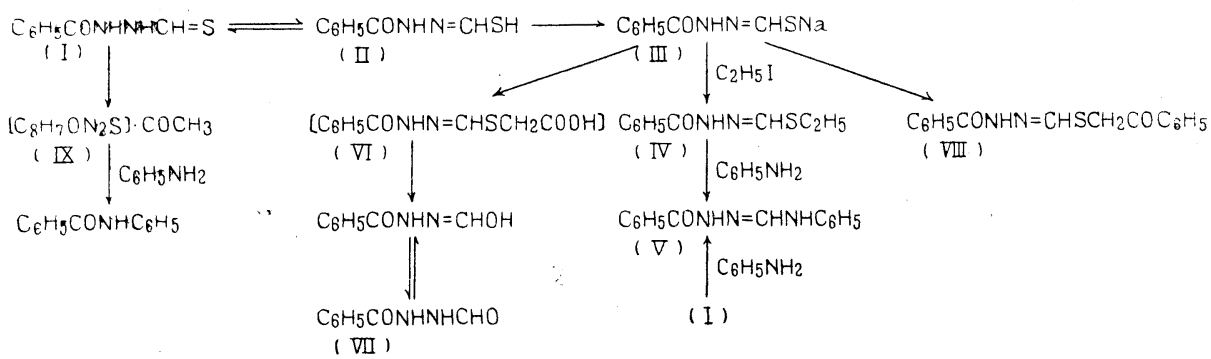

生ずる可能性がある。チオホルミルフェニルヒドラジン の場合には第 1 報で述べたように種々のアシル誘售体を 結晶として単㒕確認するてとができたが，チオホルミル ベンズヒドラジトについて種々の条件の下でアセチル化 およびベンゾイル化を武みたが，多くの場合構造不明の 油状物となるか，あるいはジベンゾイルヒドラジンを生 じ，室温で艏水酶酸を作用させた場合にモノアセチル化 合物（IX)（アセチル基の位置は明らかでない）功結晶と

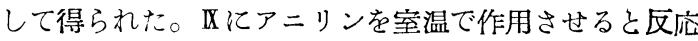
機構はわからないが,ベンズアニリドを生じることがわ かった。

チオホルミルベンズヒドラジドは濃硫酸によってほと んど分解することなく脱水閉環を起すが，塩化ベンゾィ ルあるいは塩化アセチルに対しては不安定で分解を起し てジベンゾィルヒドラジンを生じ，またチオホルミルベ ンズヒドラジドだけを加熱溶融してもやはりジベンゾィ ルヒドラジンを生じる。てれらの反応の機構は恐らくべ ンズヒドラジドを加熱あるいは酸化するとジベンゾィル ヒドラシンを生じる反応2) と類似のものと思われる。

\section{実 験 の 部}

\section{N -benzoyl-N'-ethylmercaptomethylenehydra- zine (IV)}

チオホルミルベンズヒドラジド1)（以下チオホルミル 体とよぶ） $5 \mathrm{~g}$ を $0.7 \mathrm{~g}$ の金属ナトリウムをとかしたエ タノール $30 \mathrm{cc}$ に溶解し，てれにヨウ化エチル $4.5 \mathrm{~g}$ を 加え, 一夜放置後減圧で溶媒を除去し, 残留する油状物 質に水を加え, エーテルで抽出し, ボウ硝で乾燥後エー テルを減圧で除くと, 約 $3 \mathrm{~g}$ の粘稠な暗赤色の油を得 た。約半量はただちに下記のアニリンとの反応に供し, 残部を 3 日間放置後固化したものをエタノールから再結 晶し, 無色板状結晶, $\mathrm{mp} 125^{\circ} \mathrm{C}$ (IV) $1 \mathrm{~g}$ を得た。

$\begin{array}{ccc}\text { 元素分析 } & \text { 実臨值 } & \mathrm{N} 13.20 \% \\ \mathrm{C}_{10} \mathrm{H}_{12} \mathrm{ON}_{2} \mathrm{~S} & \text { 計算值 } & \mathrm{N} 13.46 \%\end{array}$

2) G. Struve, J. pr. Chem. 50, 295 (1894); R. Stollé, ibid. 69, 154 (1904).

N-benzoyl-N'-anilinomethylenehydrazine (V)

i ) チオホルミル体 $5 \mathrm{~g}$ をエタノール $50 \mathrm{cc}$ に溶解 し，2.6g のアニリンを加えると，硫化水素を発生して 徐々に反応して結晶が析出する。常温で一夜放置後, 水 を加えてさらに沈亚を析出させ，沈殿を口過し，エタノ ールで洗う $(4.7 \mathrm{~g})$ 。エタノールから再結晶すると無色 針状結晶 $\mathrm{mp} 205^{\circ} \mathrm{C}$ (分解)（V) となる。

\section{元素分析 実験値 N $17.83 \%$ \\ $\mathrm{C}_{14} \mathrm{H}_{13} \mathrm{ON}_{3}$ 計算值 $\mathrm{N} 17.57 \%$}

ii ）前記チオホルミルベンズヒドラジドとヨウ化エチ ルから得た油状物質（粗製の IV) の半量に約 $1 \mathrm{cc} の ア$ ニリンを加えるとメルカプタンを発生して反応する。一 夜放置後水で希釈して生じた沈殿を口過，エタノールか ら再結晶すると， $\mathrm{mp} 205^{\circ} \mathrm{C}$ (分解) (V) を得た。i ) で得たものと混融しても降下を諮めない。

\section{チオホルミルベンズヒドラジドと無水酢酸との反応}

チオホルミル体 $5 \mathrm{~g}$ を $10 \mathrm{cc}$ の無水眽酸に加温溶解し て室温で放置すると，徐々に結晶を析出する。てれを口 過し，エタノールで洗浄すると $2.5 \mathrm{~g}$ の結晶を得た。エ タノールから再結晶すると無色板状晶（IX), $\mathrm{mp} 129^{\circ} \mathrm{C}$ となる。希カセイソーダに不溶である。

\section{元素分析 实験值 N $12.37 \%$ \\ $\mathrm{C}_{10} \mathrm{H}_{11} \mathrm{ON}_{2} \mathrm{~S}$ 計算値 $\mathrm{N} 12.60 \%$}

このモノアセチル化合物 $1 \mathrm{~g}$ をタノールに㲘濁し， $0.4 \mathrm{~g}$ のアニリンを室温で加えて放置すると硫化水素を 発生して徐々に反応して溶液となる。一夜放置後水で希 釈して生ずる沈殿 $(0.9 \mathrm{~g})$ を口過, エタノールから再 結晶すると, 無色板状晶, $\mathrm{mp} 160^{\circ} \sim 161^{\circ} \mathrm{C}$ (ベンズア ニリド）を得た。別に合成したベンズアニリドと湿融し ても瀜点降下を認めない。

チオホルミルベンズヒドラジドと塩化ベンゾイルまた は塩化アセチルとの反応

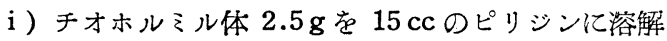
し，てれに $2 \mathrm{~g}$ (当量)の塩化ベンゾィルを氷冷かきま ぜながら滴下する。一夜放置後水を加え，析出する白色 沈殿を口過し，メチルエチルケトンから再結晶して 2.7 
$\mathrm{g}$ の結晶, $\mathrm{mp} 236^{\circ} \mathrm{C}, \mathrm{N}, \mathrm{N}^{\prime}$-ジベンゾィルヒドラジン を得た。別に合成した $\mathrm{N}, \mathrm{N}^{\prime}$-シシベンゾイルヒドラジン と湿蛔しても融点降下を認めない。この実験で $4 \mathrm{~g}$ （2 当量）の塩化ベンゾイルを用いた場合にも結晶性物筫と しては少量のジベンゾィルヒドラジンを得たのみであっ た。

ii ）チオホルミル体 $2.5 \mathrm{~g}$ を $25 \mathrm{cc}$ のアセトンに溶解 し， $1.2 \mathrm{~g}$ ( 1 当量) の炭酸水素ナトリウムを㲘濁し, 水 泠かきまぜながら $2 \mathrm{~g}$ (1 当量) の塩化ベンゾイルを滴 下し，5時間かきまぜた後，一夜放置して水で希釈する 之，黄色の油状物賀を分離し，その一部は徐々に固化し た。てれをメチルエチルケトンから再結晶して， $0.6 \mathrm{~g}$ のジベンゾイルヒドラジンを得た。同様にして 2 当量の 塩化ベンゾイルを作用させても油状物筫に伴なって少量 のジベンゾィルヒドラジンを得たのみであった。

iii）チオホルミル体のピリシン溶液に当量の塩化アセ チルを作用させ，一夜放置後水で肴秋し，一夜水冾して 白色の結晶を得た。てれをピリジンから再沈殿させた。 $\mathrm{mp} 235^{\circ} \mathrm{C}$ のジベンゾイルヒドラジンで別の合成品と混 融しても融点降下を認めない。

iv）チオホルミル体を分解点まで加熱後，アルコール から再結晶すると,やはり $\mathrm{mp} 235^{\circ} \mathrm{C}$ のジベンゾィル ヒドラジンが得られる。

チオホルミルベンズヒドラジドとモノクロル酢酸との 反応

チオホルミル体 $2 \mathrm{~g}$ を $4.5 \%$ カセイソーダ溶液 $10 \mathrm{cc}$
汇溶解し，乙れをモノクロル酶酸 $1.1 \mathrm{~g}$ の水溶液（水 $10 \mathrm{cc} ）$ を $1 \mathrm{~g}$ の炭酸水素ナトリウムで中和したものに加 光，一夜放置後 9\% の塩酸 $5 \mathrm{cc}$ で中和すると，油状物 質を分離する。一日放置すると大部分固化する。乙れを エタノ一ルから 2 回再結結晶すると $\mathrm{mp} 160^{\circ} \mathrm{C}$ のホル ミルベンゾイルヒドラジン（収量 $0.7 \mathrm{~g}$ ）を得た。

元素分析

$$
\mathrm{C}_{8} \mathrm{H}_{8} \mathrm{O}_{2} \mathrm{~N}_{2}
$$

実験値 C $58.43 \% ， \mathrm{H} 4.87 \% ， \mathrm{~N} 16.84 \%$

計算值 C $58.52 \% ， \mathrm{H} 4.91 \%, \mathrm{H} 1707 \%$ ベンゾイルヒドラジンとギ酸を熱して得たホルミルベン ゾイルヒドラジン $\left(\mathrm{mp} 160^{\circ} \mathrm{C}\right)$ と混融しても融点降下 を認めない。

チオホルミルベンズヒドラジドとクロルアセトフェノ ンとの反応

チオホルミル体 $2 \mathrm{~g}$ を $0.26 \mathrm{~g}$ の金属ナトリウムをと

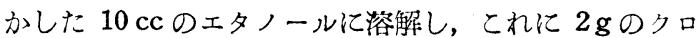

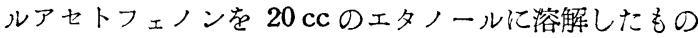
を冷却しつつ加え，一夜放置後水を加えて生じた沈殿を 口過し，エタノールから再結晶すると， mp 122〜123 ${ }^{\circ} \mathrm{C}$ の微黄色結晶フェナシルメルカプト化合物（证）(収 量 $1.6 \mathrm{~g}$ ）を得た。

\section{元素分析 実験值 N 8.78\% \\ $\mathrm{C}_{16} \mathrm{H}_{14} \mathrm{O}_{2} \mathrm{~N}_{2} \mathrm{~S}$ 計算值 $\mathrm{N} 9.39 \%$}

終りにのぞみ元素分析を担当された当教室有機分析室 の諸氏に感謝の意を表する。

（大阪市立大学理工学部生物化学教室，大阪市北区）（昭和 30 年 11 月 26 日受理）

\section{2-オキシ-2- $\left(3^{\prime}, 4^{\prime}, 5^{\prime}\right.$-トリメトキシベンジル $)-4,6$-ジメトキシクマラノン $\left(5,7,3^{\prime}, 4^{\prime}, 5^{\prime}-\right.$-ペンメチルエピアンペロプチン) の反応について}

(フラバノノール類に関する研究 第 3 報)

久保田尚志・納谷洋子・市川信孝

著者らの一人久保田は前報告2) でペンタメチルアンペ ロプチン(3-オキシ $-5,7,3^{\prime}, 4^{\prime}, 5^{\prime}$-ペンタメトキシフラバ ノン）を肴メタノール性カセイカリ溶液で短時間処理し た場合，生成するいわ叫る“ペンタメチルエピアンペロ プチン”3)に対し,ての物筫の種々の反応から2-オキシー

1） 前報（第 2 報）久保田, 新井, 本誌 76, 1069 (1955).

2) 久保田, 本誌 73, 571 (1952).
2-(3', $4^{\prime}, 5^{\prime}$-トリメトキシベンジル) $-4,6$-ジメトキシク マラノン（I）式を推定した。

今回さらにこの物資（I）について二つの反応を試み たので，その結果を報告する。

1. “ペンタメチルエピアンペロプチン”が式をも

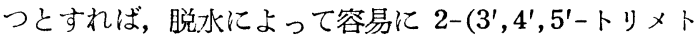
3）久保田, 本誌 59, 1160 (1938). 